\title{
Candida Tropicalis Spondylodiscits in an Immunocompetent Host: A Case Report and Literature Review
}

\section{Espondilodiscite por Candida Tropicalis em um hospedeiro imunocompetente: relato de caso e revisão da literatura}

Arthur Lopes ${ }^{1,2}$ Rafael Albanez Andrade ${ }^{1,2}$ Rebeca Gonelli Andrade 2,3

Bianca Berardo Pessoa Zirpoli ${ }^{4}$ Arthur Burgos Souto Maior ${ }^{4(}$ Gabrielly Aguiar de Lima Silva ${ }^{[®}$

Marcelo Andrade 6

${ }^{1}$ Department of Neurosurgery, Hospital da Restauração, Recife, PE, Brazil

Address for correspondence José Maia Lopes, MD, 1541 Aurora

${ }^{2}$ Centro de Referência do Nordeste em Dor, Real Hospital Português, Street, Apt 4002A, Santo Amaro, 50040-090, Recife, Brazil Recife, PE, Brazil

3 Pain Center, Instituto de Medicina Integral Professor Fernando Figueira, Recife, PE, Brazil

${ }^{4}$ Universidade Católica de Pernambuco, Recife, PE, Brazil (e-mail: arthurjlopes@gmail.com).

5 Faculdade Pernambucana de Saúde, Recife, PE, Brazil

${ }^{6}$ Department of Neurosurgery, Hospital Getúlio Vargas, Recife, PE, Brazil

Arq Bras Neurocir 2021;40(4):e412-e416.

\section{Abstract \\ Keywords \\ - spondylodiscitis \\ - candida tropicalis \\ - fungal spondylodiscitis \\ Resumo \\ Palavras-chave \\ - espondilodiscite \\ - candida tropicalis \\ - espondilodiscite fúngica}

Background Fungal spondylodiscitis is not common but should be suspected in some cases. Candida tropicalis infections are being more frequently diagnosed due to some factors related to the microorganism.

Case Description AC. tropicalis spondylodiscitis is described in a 72-year-old man who was treated with a combination of echinocandin (micafungin) and surgery.

Conclusion The presence of some risk factors should promptly raise the suspicion of fungal spondylodiscitis. Treatment should be instituted as early as possible for the best outcome for the patient.

Introdução A espondilodiscite fúngica é uma doença incomum, porém deve ser suspeitada em algumas situações. As infecções por Candida tropicalis são cada vez mais diagnosticadas devido a alguns fatores relacionados ao agente.

Descrição do Caso É descrito o caso de um homem de 72 anos, com diagnóstico de espondilodiscite causada por $C$. tropicalis, o qual foi tratado por cirurgia associada a uma equinocandina (micanfungina).

Conclusão A presença de alguns fatores de risco deve levantar a suspeita do diagnóstico de espondilodiscite fúngica. O tratamento deve ser instituído o mais precocemente possível, de maneira a obter melhor prognóstico aos pacientes. received

April 28, 2021

accepted

July 30, 2021
DOI https://doi.org/ 10.1055/s-0041-1735800. ISSN 0103-5355.

\footnotetext{
(c) 2021. Sociedade Brasileira de Neurocirurgia. All rights reserved. This is an open access article published by Thieme under the terms of the Creative Commons Attribution-NonDerivative-NonCommercial-License, permitting copying and reproduction so long as the original work is given appropriate credit. Contents may not be used for commercial purposes, or adapted, remixed, transformed or built upon. (https://creativecommons.org/ licenses/by-nc-nd/4.0/) Thieme Revinter Publicações Ltda., Rua do Matoso 170, Rio de Janeiro, RJ, CEP 20270-135, Brazil
} 


\section{Introduction}

Spondylodiscitis is a severe infection of the spine, and fungal etiology is uncommon. The most prevalent yeasts are Aspergillus and Candida. ${ }^{1,2}$ Despite being usually diagnosed in immunocompromised people, fungal invasive infections may develop due to the presence of some risk factors in immunocompetent people. Candida tropicalis is a pathogen increasingly found in invasive fungal diseases. ${ }^{3,4}$

In the present article, we report the case of a 72-year-old man who presented with severe $C$. tropicalis spondylodiscitis. We review the literature related to the etiology, diagnosis, and treatment of fungal spondylodiscitis.

\section{Case Report}

A 72-year-old man developed low back pain associated with weakness in the lower limbs with progressive worsening. During the investigation, he was diagnosed with thoracolumbar spondylodiscitis. Two months before, the patient suffered intestinal perforation and peritonitis at the time he underwent cholecystectomy. He evolved after surgery with a severe abdominal infection and long-term use of antibiotics.

Once spondylodiscitis was diagnosed, he was initially treated with antibiotics (meropenem + vancomycin) at another hospital. Since the neurological deficits of the patient did not improve and the magnetic resonance imaging (MRI) exam showed worsening of the spinal infection 8 weeks after treatment, he was forwarded for neurosurgical evaluation. (-Figs. 1 and 2)

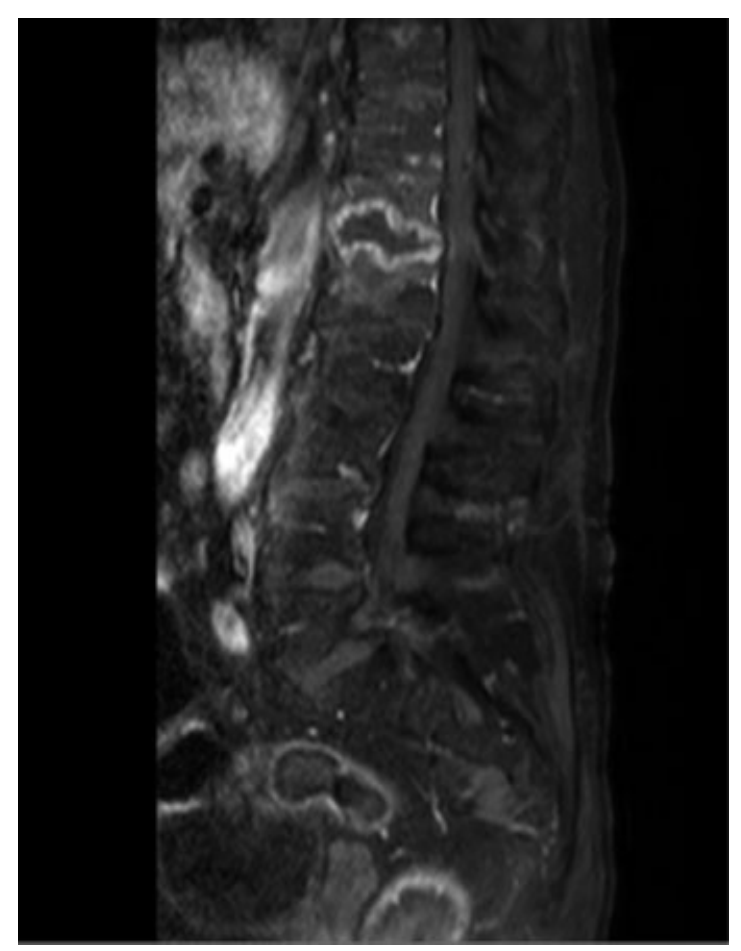

Fig. 1 Contrast-enhanced T1-weighted MRI before antibiotic treatment shows vertebral body and intervertebral disk infection.

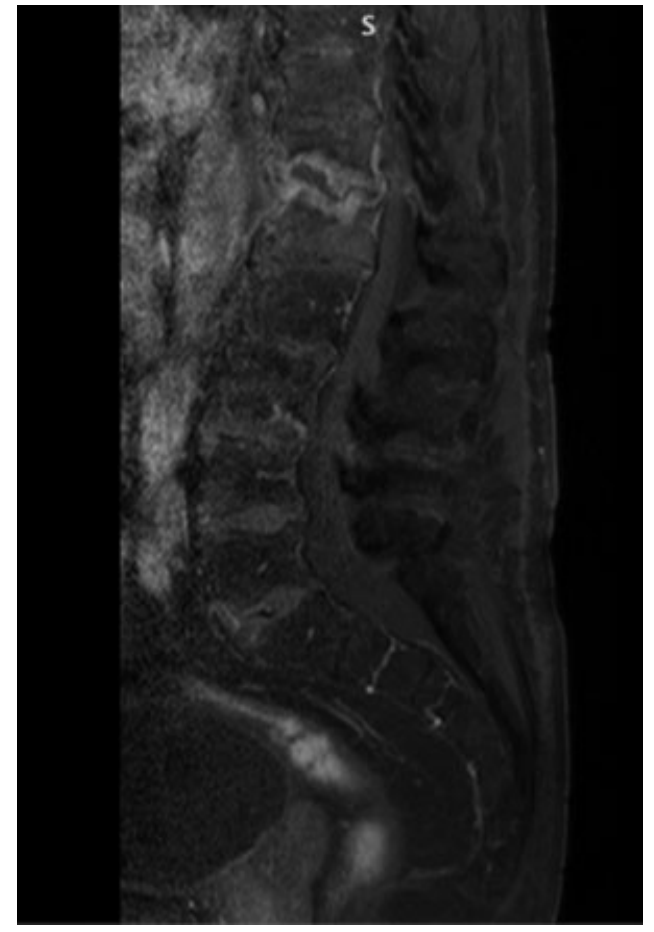

Fig. 2 Eight weeks after treatment, MRI shows T12 and L1 vertebral body collapse and epidural abscess.

On neurological examination, motor weakness (grade $3 / 5$ strength on both lower limbs) and hypoesthesia below T10 dermatome were observed.

Since the previous antibiotic treatment failed and there were signs of instability, it was decided to perform surgery to collect tissue for microbiological analysis and spinal arthrodesis.

The patient underwent T9-L4 laminectomy, T9-L4 arthrodesis, and epidural abscess drainage. Microbiological culture showed $C$. tropicalis yeasts. Micafungin was started because the fungus was sensitive in vitro. He was tested for HIV, which was negative.

Unfortunately, the patient developed sepsis and acute renal failure and died 4 weeks after surgery.

\section{Discussion}

Spinal infections are usually classified according to the etiologic agent or to the site of the infection. The most related microorganisms are bacteria, mycobacterium tuberculosis, and fungi. Some articles have also reported parasites (Echinococcosis) as pathogens causing spondylodiscitis. Pyogenic infections are the most common, mainly by Staphylococcus aureus, Escherichia coli, Proteus, Klebsiella, and Enterobacter $s p p \cdot{ }^{5-7}$ Related to location on spine structures infections may be classified as discitis, spondylitis, spondylodiscitis, facet joint infection, and epidural abscess. ${ }^{5}$ Spontaneous spondylodiscitis is usually located on the thoracic and lumbar spine and is rare on the cervical spine, although the incidence of epidural abscesses is higher in cervical cases. Complications and mortality are not related to spine site infection. ${ }^{5,8}$ 
The incidence of fungal spondylodiscitis has been progressively increasing due to an elevation of exposure to risk factors. ${ }^{1}$ The main risk factors for fungal invasive infections are immunosuppression, sepsis, broad-spectrum antibiotics, total parenteral nutrition, fungal colonization, mechanical ventilation, and diabetes..$^{9-11}$ The most common agents for fungal spinal infections are Aspergillus fumigatus, Aspergillus flavus and Candida albicans. C. tropicalis, Candida glabrata, Candida parapsilosis, Candida krusei, and Cryptococcus are other possible fungi that may cause spinal infections. ${ }^{1}$

C. tropicalis is one of the most common non-Candida Albicans Candida (NCAC) yeast. Infections by this microorganism has been progressively increasing and, nowadays, it is considered the second most virulent Candida species. Compared with other NCACs, C. tropicalis is more virulent because it exhibits dimorphism, proteinases secretion, and it is a strong biofilm producer. $C$. tropicalis infections are associated with higher mortality than others NCACs and are usually diagnosed in oncological patients with neutropenia., ${ }^{3,4}$

Gamal Tsou et al. observed that almost all fungal spondylodiscitis cases present local symptoms such as pain, tenderness, and edema. Back and lumbar pain may occasionally irradiate to the lower limbs. Fever is observed in half of the patients suffering from pyogenic spondylodiscitis, and in only $\sim 30 \%$ of the fungal spine infections. One third of the patients present neurological symptoms, such as motor weakness and sensory deficits. ${ }^{5,12}$

Laboratory studies show leukocytosis, anemia, and elevation of C-reactive protein and erythrocyte sedimentation rate levels. ${ }^{12}$

In a review of articles published up to 2016, Rami et al. studied all cases of $C$. tropicalis spondylodiscitis. Sixteen patients were $>50$ years old. They found one cervicothoracic case; nine thoracic cases; four thoracolumbar cases; and five lumbar cases. Regarding risk factors, nine patients had received antibiotic therapy and six patients had previous malignancy or chemotherapy. Six patients were treated with antifungal agents; 11 were treated with drugs associated to surgery; 1 patient underwent surgery alone; and treatment was not reported in 1 case. Neurological deficits were not reported, and only one patient died. ${ }^{13-19}$

The guidelines of the Infectious Diseases Society of America recommend fluconazole, $400 \mathrm{mg}$ for between 6 to 12 months or an echinocandin (spongin, micafungin or anidulafungin) for at least 2 weeks followed by fluconazole, $400 \mathrm{mg}$ daily, for between 6 to 12 months as the first choice for fungal spinal osteomyelitis.

Lipid formulation amphotericin B for at least 2 weeks followed by fluconazole for between 6 and 12 months may be applied as an alternative regimen. Surgical treatment is suggested for spinal instability, severe kyphosis, large epidural abscesses, and for patients who have neurological deficits and worsening or persistent symptoms despite adequate treatment. ${ }^{1,6,20}$

Ganesh et al. observed that patients who underwent antifungal therapy in combination with surgery presented lower mortality in Candida and Aspergil's infections. ${ }^{2}$

\section{Conclusions}

Spondylodiscitis is a life-threatening disease that must be diagnosed and treated as soon as possible.

Although uncommon, fungal spondylodiscitis should be suspected in patients with risk factors, that is, diabetes, broad-spectrum antibiotics, immunosuppression, sepsis, and others. The incidence of $C$. tropicalis infection increases over the years because it is a biofilm producer and exhibits proteinase secretion and dimorphism.

The combination of antifungal therapy and surgery tends to have a better prognosis for the treatment of fungal spondylodiscitis patients.

\section{Funding \\ None.}

\section{Conflict of Interests}

The authors have no conflict of interests to declare.

\section{References}

1 Caldera G, Cahueque M, Cobar A, Gómez G, Rodríguez O. Fungal spondylodiscitis: review. J Spine 2016;5:2-6

2 Ganesh D, Gottlieb J, Chan S, Martinez O, Eismont F. Fungal Infections of the Spine. Spine (Phila Pa 1976) 2015;40(12): E719-E728

3 Zuza-Alves DL, Silva-Rocha WP, Chaves GM. An Update on Candida tropicalis Based on Basic and Clinical Approaches. Front Microbiol 2017 Oct 13;8(1927):1-25

4 Silva S, Negri M, Henriques M, Oliveira R, Williams DW, Azeredo J. Candida glabrata, Candida parapsilosis and Candida tropicalis: biology, epidemiology, pathogenicity and antifungal resistance. FEMS Microbiol Rev 2012;36(02):288-305

5 Tsantes A, Papadopoulos D, Vrioni G, Sioutis S, Sapkas G, Benzakour A, et al. Spinal Infections: An Update. Microorganisms 2020 Mar 27;8(476):1-18

6 Gouliouris T, Aliyu SH, Brown NM. Spondylodiscitis: update on diagnosis and management. J Antimicrob Chemother 2010;65 (Suppl 3):iii11-iii24

7 Mavrogenis AF, Megaloikonomos PD, Igoumenou VG, et al. Spondylodiscitis revisited. EFORT Open Rev 2017;2(11):447-461

8 Stangenberg $\mathrm{M}$, Mohme $\mathrm{M}$, Mende $\mathrm{KC}$, et al. Impact of the localization on disease course and clinical management in spondylodiscitis. Int J Infect Dis 2020;99:122-130

9 Muskett H, Shahin J, Eyres G, Harvey S, Rowan K, Harrison D. Risk factors for invasive fungal disease in critically ill adult patients: a systematic review. Crit Care 2011;15(06):1-15

10 Tufano R. Focus on risk factors for fungal infections in ICU patients. Minerva Anestesiol 2002;68(04):269-272

11 Jorge VC, Cardoso C, Noronha C, Simões J, Riso N, Vaz Riscado M. 'Fungal spondylodiscitis in a non immunocompromised patient'. BMJ Case Rep 2012;bcr1220115337:1-6

12 Gamaletsou MN, Kontoyiannis DP, Sipsas NV, et al. Candida osteomyelitis: analysis of 207 pediatric and adult cases (1970-2011). Clin Infect Dis 2012;55(10):1338-1351

13 Rami AY, Sotirios MG, Lukas L, Frank H, Jorge F. Fungal Spondylodiscitis: Unexpected Diagnosis, Case Report and Literature Review. J Spine 2016;5(03):1-6

14 Eisen DP, MacGinley R, Christensson B, Larsson L, Woods ML. Candida tropicalis vertebral osteomyelitis complicating epidural catheterisation with disease paralleled by elevated Darabinitol/L-arabinitol ratios. Eur J Clin Microbiol Infect Dis 2000;19(01):61-63 
15 Sebastiani GD, Galas F. Spondylodiscitis due to Candida tropicalis as a cause of inflammatory back pain. Clin Rheumatol 2001;20 (06):435-437

16 Hendrickx L, Van Wijngaerden E, Samson I, Peetermans WE. Candidal vertebral osteomyelitis: report of 6 patients, and a review. Clin Infect Dis 2001;32(04):527-533

17 Miller DJ, Mejicano GC. Vertebral osteomyelitis due to Candida species: case report and literature review. Clin Infect Dis 2001;33 (04):523-530
18 Shaikh Z, Shaikh S, Pujol F, Trauber D, Sam M. Candida tropicalis osteomyelitis: case report and review of literature. Am J Med 2005;118(07):795-798

19 Chia SL, Tan BH, Tan CT, Tan SB. Candida spondylodiscitis and epidural abscess: management with shorter courses of antifungal therapy in combination with surgical debridement. J Infect 2005;51(01):17-23

20 Pappas PG, Kauffman CA, Andes DR, et al. Clinical Practice Guideline for the Management of Candidiasis: 2016 Update by the Infectious Diseases Society of America. Clin Infect Dis 2016;62(04):e1-e50 